\title{
THE EFFECT OF AMMONIUM SULPHATE (ZA) FERTILIZER CONCENTRATION ON THE GROWTH OF MICROALGA POPULATION (Nannochloropsis oculata)
}

\author{
Rony Andes Fery*1, Syafruddin Nasution ${ }^{2}$, Sofyan Husein Siregar ${ }^{2}$ \\ ${ }^{1}$ Student of The Faculty of Fisheries and Marine Universitas Riau, Pekanbaru \\ ${ }^{2}$ Lecturer at The Faculty of Fisheries and Marine Universitas Riau, Pekanbaru \\ *rafysyrony@gmail.com
}

\begin{abstract}
This research was conducted from 24 June to 6 July 2019 in the Regional Technical Implementation Unit of the Seawater and Brackish Aquaculture Fisheries Center (UPTD BPBALP Teluk Buo), West Sumatra. This study aim to determine the effect of Ammonium Sulfate $\left(\left(\mathrm{NH}_{4}\right)_{2} \mathrm{SO}_{4}\right)$ with different concentrations on the growth rate of Nannochloropsis oculata microalgae population. The method used in this study is an experimental method using a completely randomized design (CRD) one factor, namely ZA fertilizer concentration. There were 5 (five) levels concentration tested, namely $0 \mathrm{ml} / \mathrm{L}$ (control treatment), $30 \mathrm{ml} / \mathrm{L}$ (treatment A), $40 \mathrm{ml} / \mathrm{L}$ (treatment B), $50 \mathrm{ml} / \mathrm{L}$ (treatment C), and $60 \mathrm{ml} / \mathrm{L}$ (treatment D) total of 15 treatment units. The test organism in this study was $N$. oculata. The container used is a glass jar (2 liter capacity). The test parameters in this study are the maximum cell population density achieved during 5 days of maintenance (120 hours), relative growth, self-doubling time and specific growth rate during the exponential growth phase. The results of this study indicate that the best concentration of ZA fertilizer for cell population growth is $40 \mathrm{ml} / \mathrm{L}$, followed by a concentration of $30 \mathrm{ml} / \mathrm{L}$, a concentration of $50 \mathrm{ml} / \mathrm{L}$, a concentration of 60 $\mathrm{ml} / \mathrm{L}$ and the lowest at a concentration of $0 \mathrm{ml} / \mathrm{L}$ (control).
\end{abstract}

Keywords: ZA fertilizer, Concentration, Population growth, Nannochloropsis oculata.

\section{PENDAHULUAN}

Nannochloropsis oculata adalah salah satu mikroalga bersel satu yang termasuk dalam kelas Eustigmatophyceae dan umumnya dikultur pada pembenihan ikan sebagai pakan rotifer (zooplankton). Spesies ini mempunyai peranan penting dalam suatu kegiatan pembenihan karena kandungan nutrisinya yang tinggi. N.oculata memiliki sejumlah kandungan gizi dan pigmen seperti protein $(52,11 \%)$, karbohidrat (16\%), lemak (27,64\%), vitamin C $(0,85 \%)$ dan klorofil A $(0,89 \%)$ (Anon et al., 2009).
Unsur hara yang dibutuhkan mikroalga terdiri dari mikronutrien dan makronutrien. Makronutrien antara lain $\mathrm{C}$ (Karbon), $\mathrm{H}$ (hidrogen), $\mathrm{N}$ (nitrogen), $\mathrm{P}$ (fosfor), $\mathrm{K}$ (kalium), $\mathrm{S}$ (sulfur), $\mathrm{Mg}$ (magnesium) dan $\mathrm{Ca}$ (Kalsium), sedangkan mikronutrien seperti $\mathrm{Fe}, \mathrm{Cu}, \mathrm{Zn}, \mathrm{Mn}, \mathrm{B}$, dan Mo (Andersen, 2005). Setiap unsur hara makro dan mikro ini mempunyai fungsi pada pertumbuhan mikroalga. Unsur Nitrogen dalam medium kultur berfungsi untuk membentuk protein, lemak dan hijau daun (klorofil).

Produksi mikroalga sebagai pakan untuk organisme akuatik membutuhkan 
biaya yang tinggi (Ceballos et al., 2006). Salah satu faktor penyebab tingginya biaya produksi mikroalga adalah tingginya biaya media kultur terutama media yang mengandung senyawa murni yang dibuat khusus untuk kultur mikroalga. Solusinya yaitu penggunaan media tumbuh yang lebih murah seperti pupuk yang biasa digunakan oleh kegiatan pertanian dalam kultur mikroalga. Pupuk ZA adalah pupuk kimia buatan yang mengandung Amonium Sulfat yang dirancang untuk memberi tambahan hara nitrogen dan belerang bagi tanaman.

Nama ZA adalah singkatan dari istilah bahasa Belanda, Zwavelzure Ammoniak, yang mengandung belerang 24\% (dalam bentuk Sulfat) dan Nitrogen $21 \%$ (dalam bentuk amonium). Pemilihan jenis pupuk ini didasari pertimbangan bahwa pupuk ini sangat mudah ditemukan di pasaran sehingga memiliki potensi sebagai pengganti pupuk komersial yang umum digunakan dalam skala laboratorium seperti pupuk Walne (Campaña-Torres et al., 2012).

Balai Perikanan Budidaya Air Laut dan Payau (BPBALP) Teluk Buo, telah mengembangkan usaha budidaya ikan dan udang dengan sistem tambak beton sehingga membutuhkan pakan alami bagi larva ikan dan udang yang memiliki kualitas baik dan jumlah yang tersedia secara kontinyu.
Masalah dalam penelitian ini adalah bagaimana pengaruh konsentrasi Ammonium Sulfat $\left(\left(\mathrm{NH}_{4}\right)_{2} \mathrm{SO}_{4}\right)$ dengan konsentrasi yang berbeda terhadap pertumbuhan populasi $N$. oculata? Penelitian ini terinspirasi dari penelitian yang sudah dilakukan oleh (Muklis et al., 2017) bahwa kepadatan populasi sel maksimum $N$. oculata tertinggi dicapai pada konsentrasi pupuk ZA $40 \mathrm{mg} / \mathrm{L}$ dengan tingkat kepadatan populasi sel sebesar $12.950 \times 10^{3} \mathrm{sel} / \mathrm{mL}$ yang dicapai pada jam ke -72 setelah penebaran.

\section{METODE PENELITIAN}

Penelitian ini telah dilaksanakan pada bulan Agustus 2018 yang bertempat di sekitar perairan Meral, Kabupaten Karimun Provinsi Kepulauan Riau. Analisis sampel diatom dilakukan di Laboratorium Biologi Laut sedangkan analisis nitrat, fosfat dan silikat dilakukan di Laboratorium Kimia Laut, Jurusan Ilmu Kelautan Fakultas Perikanan dan Kelautan Universitas Riau.

Metode yang digunakan dalam penelitian ini adalah metode survey, pengambilan sampel dilakukan pada saat air laut pasang. Penentuan titik lokasi penelitian dengan menggunakan purposive sampling dengan memperhatikan aktivitas yang berada disekitar perairan Meral, Lokasi penelitian dibagi atas empat stasiun dengan jarak stasiun kurang lebih 200 (Gambar 1).

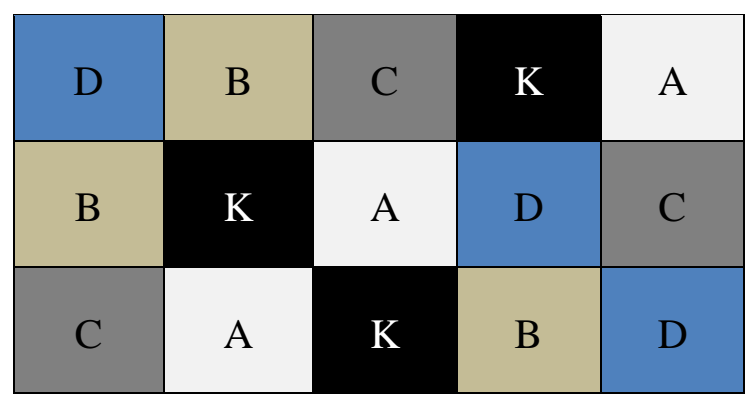

Gambar 1. Letak unit percobaan setelah dilakukan pengacakan

Keterangan:

a) Perlakuan A: $30 \mathrm{ml} / \mathrm{L} \mathrm{c}$ ) Perlakuan C: $50 \mathrm{ml} / \mathrm{L} \mathrm{e}$ ) Perlakuan K: 0 ml/L

b) Perlakuan B: $40 \mathrm{ml} / \mathrm{L} \mathrm{d}$ ) Perlakuan D: $60 \mathrm{ml} / \mathrm{L}$ 


\section{Kepadatan Populasi Sel}

Menurut Mukhlis et al. (2017) kepadatan populasi sel dapat dihitung dengan rumus:

$$
\mathbf{P}=\mathrm{N} \times 10^{4} \mathrm{sel} / \mathrm{ml}
$$

Keterangan:

$\mathrm{P}=$ Kepadatan Populasi sel $(\mathrm{sel} / \mathrm{ml})$

$\mathrm{N}=$ Jumlah total sel pada bidang haemocytometer seluas $1 \mathrm{~mm}^{2}$

\section{Laju Pertumbuhan Relatif (Relative Growth Rate)}

Laju pertumbuhan relatif adalah peningkatan jumlah sel per unit sel yang ada per lama waktu. Menurut Mukhlis et al. (2017) laju pertumbuhan relatif dapat dihitung dengan rumus:

$$
\mathbf{R G R}=\left(\left(\mathbf{C t}-\mathbf{C}_{0}\right) / \mathbf{C}_{\mathbf{0}}\right) \times 100 \%
$$

Keterangan:

$$
\begin{array}{ll}
\mathrm{RGR}= & \text { Relative growth rate }(\%) \\
\mathrm{C}_{0}= & \text { Kepadatan populasi sel } / \mathrm{ml} \text { pada } \\
& \text { awal periode pengamatan } \\
& \begin{array}{l}
\text { Kepadatan populasi sel } / \mathrm{ml} \text { pada } \\
\text { akhir periode pengamatan }
\end{array} \\
\mathrm{C}_{\mathrm{t}} &
\end{array}
$$

\section{Laju Pertumbuhan Spesifik (Spesific Growth Rate)}

Laju pertumbuhan spesifik adalah perubahan jumlah sel seiring perubahan waktu. Menurut Mukhlis et al. (2017) laju pertumbuhan spesifik dapat dihitung dengan rumus:

$$
\mathrm{SGR}=\left(\left(\mathrm{Ct} / \mathrm{C}_{0}\right)^{1 / \mathrm{t}}-1\right) \times 100 \%
$$

Keterangan:

$$
\begin{aligned}
\mathrm{SGR}= & \text { Spesific growth rate }(\% \text { per jam }) \\
\mathrm{C}_{0}= & \text { Kepadatan populasi sel } / \mathrm{ml} \text { pada } \\
& \text { awal periode pengamatan } \\
\mathrm{Ct}= & \text { Kepadatan populasi sel } / \mathrm{ml} \text { pada } \\
& \text { akhir periode pengamatan } \\
\mathrm{T}= & \text { Lama periode pengamatan }(\mathrm{jam})
\end{aligned}
$$

\section{Waktu penggandaan diri (double time)}

Waktu penggandaan diri adalah waktu yang dibutuhkan untuk membuat jumlah sel menjadi 2 kali lipat. Menurut Mukhlis et al. (2017) waktu penggandaan diri (double time) dapat dihitung dengan rumus:

$$
\mathrm{DT}=\log (2) \times \Delta t /\left(\log C t-\log C_{0}\right)
$$

Keterangan:

$$
\begin{aligned}
\mathrm{DT} & =\text { Double time }(\mathrm{jam}) \\
\mathrm{C}_{0}= & \begin{array}{l}
\text { Kepadatan populasi sel } / \mathrm{ml} \text { pada } \\
\text { awal periode pengamatan }
\end{array} \\
\mathrm{C}_{\mathrm{t}}= & \begin{array}{l}
\text { Kepadatan populasi sel } / \mathrm{ml} \text { pada } \\
\text { akhir periode pengamatan }
\end{array} \\
\Delta \mathrm{t}= & \begin{array}{l}
\text { Lama waktu dalam satu periode } \\
\text { pengamatan (jam) }
\end{array}
\end{aligned}
$$

\section{HASIL DAN PEMBAHASAN}

\section{Pertumbuhan Populasi $N$. oculata}

Pertumbuhan populasi $N$. oculata tertinggi dengan perlakuan konsentrasi pupuk Ammonium sulfat $40 \mathrm{ml} / \mathrm{L}$ yaitu pada hari ke 5 sebanyak $18.910 \times 10^{3} \mathrm{sel} / \mathrm{ml}$ dan pertumbuhan populasi sel yang terendah pada perlakuan konsentrasi $0 \mathrm{ml} / \mathrm{L}$ (kontrol) yaitu sebanyak $11.840 \times 10^{3}$ $\mathrm{sel} / \mathrm{ml}$. Hasil pengamatan menunjukkan bahwa pemberian pupuk Ammonium Sulfat (pupuk ZA) dengan konsentrasi berbedabeda memberikan pengaruh tingkat pertumbuhan populasi sel maksimum yang beragam.

Hari pertama didapati hasil pertumbuhan populasi tertinggi dicapai pada perlakuan B yaitu sebesar $7.540 \times 103$ $\mathrm{sel} / \mathrm{ml}$ dan pertumbuhan populasi yang terendah terdapat pada perlakuan kontrol yaitu sebesar $5.250 \times 10^{3} \mathrm{sel} / \mathrm{ml}$ karena pada perlakuan kontrol tidak terdapat sumber hara untuk pertumbuhan $N$. oculata. 


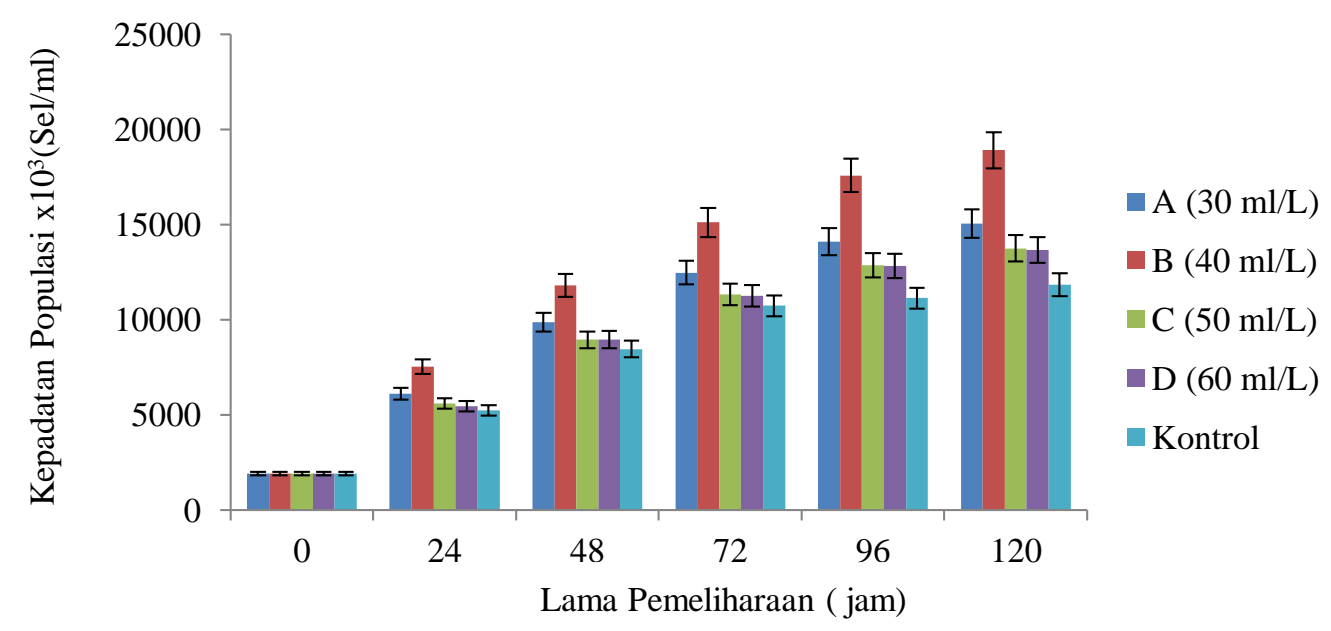

Gambar 2. Pertumbuhan populasi N. oculata berdasarkan lama pemeliharaan

Menurut Riduan et al. (2015) menyatakan bahwa nutrien yang larut dalam badan air langsung dimanfaatkan oleh fitoplankton untuk pertumbuhannya sehingga populasi dan kelimpahannya meningkat. Hari kedua, pertumbuhan populasi masih terus meningkat dan tertinggi masih diperoleh perlakuan $\mathrm{B}$ sebesar $11.810 \times 10^{3} \mathrm{sel} / \mathrm{ml}$ dan yang terendah terdapat pada perlakuan kontrol sebesar $8.470 \times 10^{3} \mathrm{sel} / \mathrm{ml}$.

Hari ke-3 dan ke-4, pertumbuhan populasi tertinggi masih dicapai oleh perlakuan $\mathrm{B}$, sedangkan pertumbuhan populasi terendah masih didapat pada perlakuan kontrol. Pada hari tersebut, perlakuan $\mathrm{C}$ dan $\mathrm{D}$ masih memiliki hasil pertumbuhan populasi yang hampir sama atau tidak berbeda nyata. Ketika hari terakhir (hari ke-5), pertumbuhan populasi sel maksimum dari urutan tertinggi secara berurutan dicapai oleh konsentrasi perlakuan B $40 \mathrm{ml} / \mathrm{L}\left(18.910 \times 10^{3} \mathrm{sel} / \mathrm{ml}\right)$, perlakuan A $30 \mathrm{ml} / \mathrm{L}\left(15.050 \times 10^{3} \mathrm{sel} / \mathrm{ml}\right)$, perlakuan C $50 \mathrm{ml} / \mathrm{L}\left(13.750 \times 10^{3} \mathrm{sel} / \mathrm{ml}\right)$, perlakuan D $60 \mathrm{ml} / \mathrm{L}\left(13.670 \times 10^{3} \mathrm{sel} / \mathrm{ml}\right)$, dan kontrol $0 \mathrm{ml} / \mathrm{L}\left(11.840 \times 10^{3} \mathrm{sel} / \mathrm{ml}\right)$.

Meskipun pada konsentrasi $0 \mathrm{ml} / \mathrm{L}$ tidak dilakukan penambahan pupuk ZA sebagai sumber nitrogen namun pertumbuhan populasi sel tetap berlangsung dan diduga karena mikroalga memanfaatkan unsur nitrogen yang tersedia secara alami dalam media air laut sebagai media kultur meskipun tersedia dalam jumlah yang sangat terbatas. Ini sesuai dengan penjelasan $\mathrm{Hu}$ (2004) bahwa ketika kandungan nitrogen turun dibawah nilai ambang batas, fotosintesis masih dapat berlanjut, meskipun berada pada tingkat yang lebih rendah.

Peningkatan ketersediaan pupuk ZA dari $30 \mathrm{ml} / \mathrm{L}$ hingga $40 \mathrm{ml} / \mathrm{L}$ telah terbukti meningkatkan pertumbuhan, namun demikian konsentrasi yang terus ditingkatkan melebihi $40 \mathrm{ml} / \mathrm{L}$ akan memberikan respon sebaliknya. Menurut Mukhlis et al. (2017) mengatakan bahwa kepadatan populasi sel yang tertinggi dicapai oleh konsentrasi $40 \mathrm{ml} / \mathrm{L}(12.950 \mathrm{x}$ $10^{3} \mathrm{sel} / \mathrm{ml}$ ) dan kepadatan populasi yang terendah didapati oleh konsentrasi 100 $\mathrm{ml} / \mathrm{L}\left(6.397 \times 10^{3} \mathrm{sel} / \mathrm{ml}\right)$.

Berdasarkan hasil analisis variansi (ANOVA), mendapatkan hasil yang sangat berbeda nyata karena pada konsentrasi yang berbeda pada setiap perlakuan memiliki nilai signifikan sebesar $0,03<$ 0,05. Kemudian dilakukan uji lanjut Least Significant Difference (LSD), dari output yang didapat ada beberapa perlakuan yang memiliki hasil hampir sama atau tidak berbeda nyata karena mendapatkan nilai signifikan > 0,05, antara lain perlakuan kontrol dengan perlakuan $60 \mathrm{ml} / \mathrm{L}$ (sig. 
0,058), dan perlakuan $50 \mathrm{ml} / \mathrm{L}$ dengan perlakuan $60 \mathrm{ml} / \mathrm{L}$ (sig. 0,903).

\section{Laju Pertumbuhan Relatif (RGR)}

Pola pertumbuhan populasi sel $N$. oculata pada perlakuan konsentrasi B (40 $\mathrm{ml} / \mathrm{L}$ ) mendapatkan rata-rata pertumbuhan relatif harian yang tinggi dari awal sampai akhir periode pengkulturan daripada perlakuan lainnya yaitu pada kisaran 7,56 $292,71 \%$. Dibandingkan dengan pola pertumbuhan populasi sel pada perlakuan konsentrasi A, C, D, dan kontrol memiliki nilai yang relatif hampir sama dari awal sampai akhir periode pengamatan yaitu pada kisaran 3,72 - 219,27\% , disajikan pada Gambar 3.

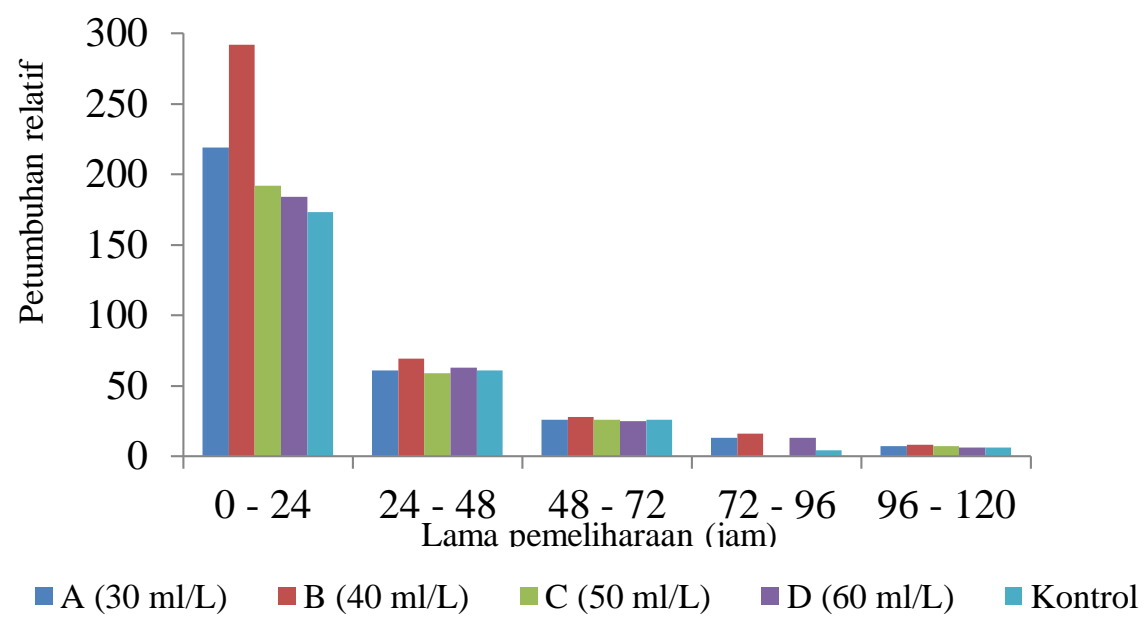

Gambar 3. Laju pertumbuhan relatif $N$. oculata berdasarkan lama pemeliharaan

Berdasarkan data laju pertumbuhan relatif pada periode pertama (jam ke-0 s/d jam ke-24) menunjukkan nilai diatas $100 \%$ yaitu antara $173,44 \%$ sampai $292,71 \%$ yang artinya bahwa peningkatan kepadatan populasi sel pada akhir periode ini mengalami peningkatan lebih dari satu kali lipat dari awal penebaran dan hal ini memenuhi kriteria sebagai fase pertumbuhan eksponensial. Data yang berbeda ditunjukkan oleh pertumbuhan relatif pada periode ke-2 (jam ke-24 s/d jam ke-48) perlakuan $\mathrm{B}$ yang tertinggi sedangkan perlakuan $\mathrm{C}$ yang terendah, dan periode ke-3 (jam ke-48 s/d jam ke-72) perlakuan $\mathrm{B}$ yang tertinggi sedangkan perlakuan $\mathrm{D}$ yang terendah dimana nilai rata-rata pertumbuhan relatif yang diperoleh berada dibawah nilai $100 \%$ dan hal terlihat disemua perlakuan yang hasilnya antara 25,78\% sampai 69,89\%. Periode ke-4 (jam ke-72 s/d jam ke-96) dan periode ke-5 (jam ke-96 s/d jam ke-120) perlakuan $\mathrm{B}$ yang tertinggi sedangkan perlakuan kontrol yang terendah, kedua fase ini sudah memasuki fase deklinasi (penurunan laju pertumbuhan) yang hasilnya berkisar antara $3,72 \%$ sampai $16,27 \%$. fase ini ditandai dengan pembelahan sel tetap terjadi, namun tidak selaju pada fase sebelumnya sehingga laju pertumbuhannya pun menjadi menurun (Kartikasari, 2010).

Menurut Riesya (2013), menyatakan bahwa ketika unsur nitrogen diturunkan konsentrasinya maka pembentukkan klorofil menjadi terhambat yang mengakibatkan proses fotosintesis terhambat sehingga mengakibatkan pertumbuhan tehambat pula. Menurut Mukhlis et al. (2017) mengatakan bahwa pada konsentrasi ZA $0 \mathrm{mg} / \mathrm{L}, 20 \mathrm{mg} / \mathrm{L}, 40$ $\mathrm{mg} / \mathrm{L}$ dan perlakuan kontrol yang terjadi hingga jam ke-72 menunjukkan 
peningkatan pertumbuhan yang relatif stabil terlihat dari nilai pertumbuhan relatif pada periode terakhir yang cenderung lebih tinggi $(14,75 \%-26,83 \%)$ dibandingkan dengan konsentrasi $60 \mathrm{mg} / \mathrm{L}, 80 \mathrm{mg} / \mathrm{L}$ dan $100 \mathrm{mg} / \mathrm{L}(-12,26 \% \mathrm{~s} / \mathrm{d} 1,63 \%)$.

\section{Laju Pertumbuhan Spesifik pada Fase Pertumbuhan Eksponensial}

$\begin{aligned} & \text { Laju pertumbuhan spesifik } \mathrm{N} \\ & \text { oculata pada fase pertumbuhan }\end{aligned}$ eksponensial setiap perlakuan konsentrasi pupuk yang berbeda yang tertinggi yaitu pada konsentrasi pupuk $40 \mathrm{ml} / \mathrm{L}$ dengan nilai sebesar $5,92 \%$ per jam dan laju pertumbuhan spesifik yang terendah terdapat pada perlakuan kontrol yaitu sebesar $4,31 \%$ perjam, disajikan pada Gambar 4.

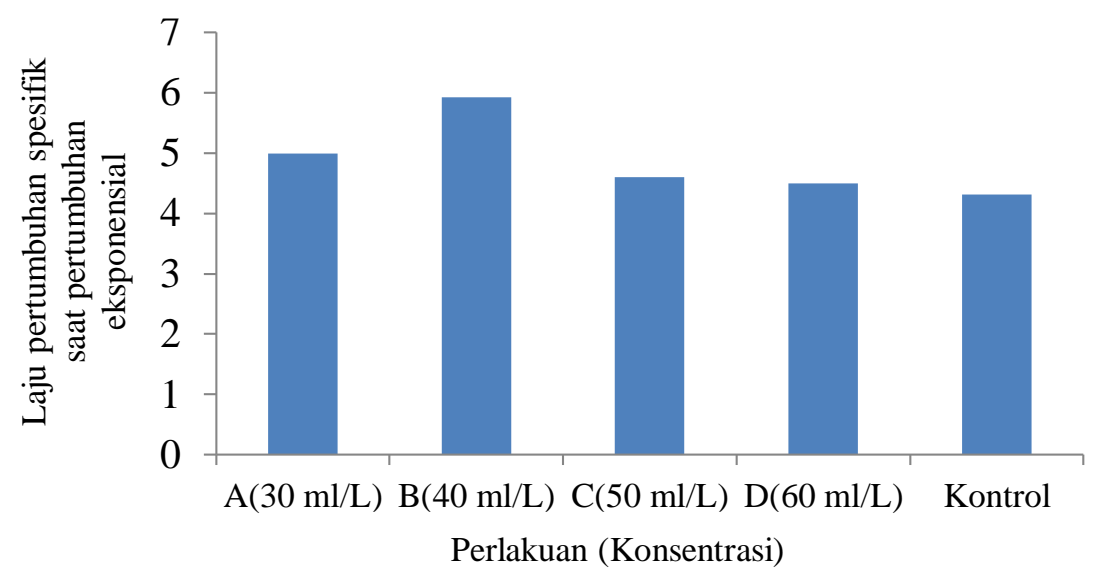

Gambar 4. Laju pertumbuhan spesifik N. oculata berdasarkan konsentrasi pupuk ZA

Laju pertumbuhan spesifik yang terjadi saat fase pertumbuhan eksponensial yang tertinggi yaitu terdapat pada konsentrasi pupuk $40 \mathrm{ml} / \mathrm{L}$. Pada perlakuan ini pertumbuhan populasi sel $N$. oculata mengalami peningkatan dengan laju pertumbuhan sebesar $5,92 \%$ per jam. Laju pertumbuhan spesifik yang terjadi saat fase pertumbuhan eksponensial pada perlakuan $\mathrm{C}$ dan $\mathrm{D}$ hampir sama yang hasilnya yaitu $4,60 \%$ dan $4,50 \%$. Sesuai dengan pernyataan Afriza et al. (2015) terkadang konsentrasi bahan yang terlalu tinggi membuat bahan sulit diserap oleh sel. Laju pertumbuhan spesifik yang terjadi saat fase pertumbuhan eksponensial yang terendah yaitu terdapat pada konsentrasi pupuk 0 $\mathrm{ml} / \mathrm{L}$ (kontrol) hanya sebesar $4,31 \%$ per jam.

Nilai laju pertumbuhan dapat dijadikan sebagai tolak ukur untuk mengetahui daya dukung media terhadap pertumbuhan $N$. oculata semakin cepat laju pertumbuhan maka semakin baik daya dukung media pupuk terhadap pertumbuhan populasi sel tersebut. Menurut Mukhlis et al. (2017) mengatakan bahwa laju pertumbuhan spesifik pada fase pertumbuhan eksponensial tertinggi dicapai oleh konsentrasi $40 \mathrm{ml} / \mathrm{L}$ dengan laju pertumbuhan rata-rata 5,69 \% per jam dan yang terendah dicapai oleh konsentrasi 100 $\mathrm{ml} / \mathrm{L}$ dengan laju pertumbuhan rata-rata $4,12 \%$ per jam.

Waktu Penggandaan Diri (Double Time)

Waktu penggandaan diri yang dibutuhkan $N$. oculata tersingkat ditunjukkan oleh konsentrasi pupuk ZA 40 $\mathrm{ml} / \mathrm{L}$ dengan nilai rata-rata sebesar 12,04 jam atau 12 jam 4 menit. Waktu penggandaan diri paling panjang ditunjukkan oleh perlakuan kontrol (tanpa pupuk ZA) dengan nilai rata-rata sebesar 16, 53 jam atau 16 jam 53 menit, disajikan pada Gambar 5. 


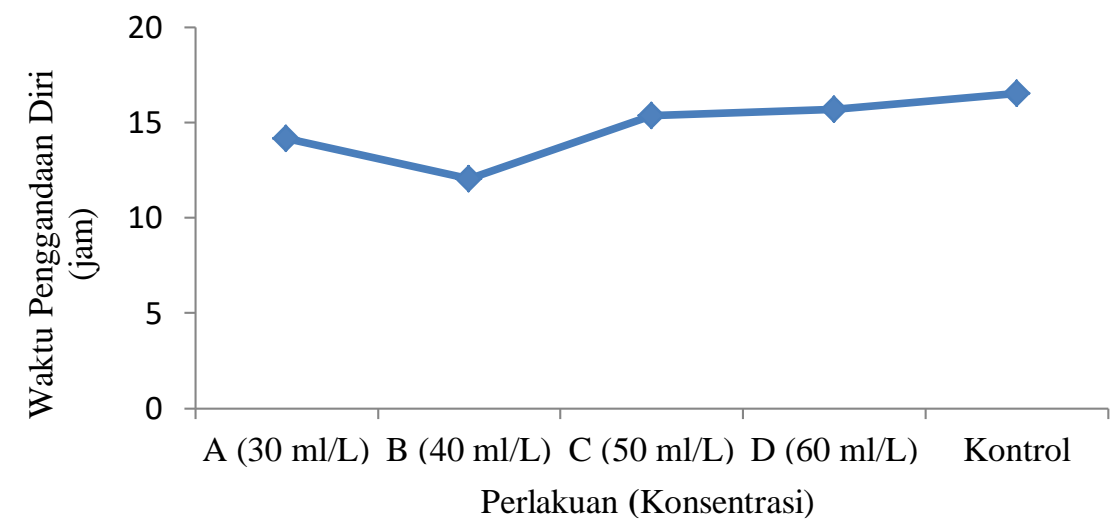

Gambar 5. Waktu penggandaan diri N. oculata berdasarkan konsentrasi pupuk ZA

Double Time (waktu penggandaan diri) N. oculata tersingkat atau paling cepat ditunjukkan oleh konsentrasi pupuk ZA 40 $\mathrm{ml} / \mathrm{L}$ dengan nilai rata-rata sebesar 12,04 jam atau 12 jam 4 menit. Perlakuan A (30 $\mathrm{ml} / \mathrm{L})$ memiliki waktu penggandaan diri selama 14,16 jam atau 14 jam 16 menit, dan sedangkan perlakuan C $(50 \mathrm{ml} / \mathrm{L})$ dan $\mathrm{D}(60 \mathrm{ml} / \mathrm{L})$ memiliki waktu penggandaan yang hampir sama yaitu berada dikisaran 15,37 sampai 15,70 jam. Waktu penggandaan diri paling panjang atau paling lama ditunjukkan oleh perlakuan kontrol (tanpa pupuk ZA) dengan nilai ratarata sebesar 16,53 jam atau 16 jam 52 menit. Ini sesuai pernyataan Afriza et al. (2015) waktu generasi yang lebih rendah berarti pertumbuhan jumlah populasi lebih cepat karena waktu yang diperlukan untuk pembelahan sel lebih singkat sehingga untuk mencapai kepadatan maksimum lebih cepat.

Menurut Mukhlis et al. (2017) mengatakan bahwa waktu penggandaan diri $N$. oculata tersingkat ditunjukkan oleh konsentrasi $40 \mathrm{ml} / \mathrm{L}$ dengan nilai rata-rata sebesar 12,52 jam atau 12 jam 52 menit. Menurut Daefi (2016) pemberian dosis urea 50 ppm dalam media pupuk pertanian merupakan dosis yang paling efektif untuk meningkatkan pertumbuhan (kepadatan populasi, laju pertumbuhan spesifik dan waktu generasi) Nannochloropsis sp. Data pertumbuhan populasi sel yang diperoleh didukung juga oleh faktor fisika, kimia, dan biologi. Suhu yang digunakan untuk pertumbuhan populasi pada penelitian ini yaitu antara $24^{\circ} \mathrm{C}$ dimana suhu ini sangat optimal bagi pertumbuhan $N$. oculata. Menurut Rostini (2007) beberapa spesies Nannochloropsis sp. air laut dapat mentoleril kondisi lingkungan yang relatif bervariasi. Spesies ini tumbuh baik pada suhu $20^{\circ} \mathrm{C}$, tetapi tumbuh lambat pada suhu $32^{\circ} \mathrm{C}$ dan tumbuhan sangat baik sekitar 20$25^{\circ} \mathrm{C}$.

Salinitas yang digunakan untuk seluruh perlakuan diatur pada tingkat 27 ppt. Salinitas optimal untuk pertumbuhan N. oculata adalah berkisar antara 33-35 ppt serta didukung oleh pendapat bahwa Speises ini dapat berkembang dengan baik pada salinitas $31 \mathrm{ppt}$ dan dapat terus menerus berkembang pada kisaran salinitas 22-49 ppt (Hu dan Gao, 2006). Derajat keasaman $(\mathrm{pH})$ dalam penelitian ini memiliki nilai yaitu 7 yang berarti bahwa $N$. oculata dapat tumbuh optimal dalam medium pertumbuhannya. Hasil pengukuran $\mathrm{pH}$ dalam penelitian ini juga didukung oleh penelitian yang dilakukan oleh Dominic et al. (2009) yaitu pH yang digunakan untuk pertumbuhan berkisar antara 6 - 9 dimana kondisi $\mathrm{pH}$ tersebut dapat tumbuh optimal.

Penelitian ini memiliki rata-rata intensitas cahaya yang digunakan yaitu 1000 lux sehingga populasi dapat tumbuh 
optimal. Cahaya dengan karakteristik intensitas saturasi untuk spesies mikroalga tertentu harus didistribusikan secara homogen ke seluruh volume unit budidaya. Dalam praktiknya, ini tidak mungkin karena penyerapan cahaya oleh pigmen mikroalga dan hamburan cahaya karena sel dan partikel lain dalam larutan kultur (Ogbonna dan Tanaka, 2000; Pottier et al., 2005).

\section{KESIMPULAN DAN SARAN}

\section{Kesimpulan}

Berdasarkan hasil penelitian disimpulkan bahwa perlakuan media kultur antar konsentrasi pupuk ZA memperlihatkan pengaruh berbeda nyata antar perlakuan yang diberikan terhadap pertumbuhan populasi sel. Pertumbuhan populasi sel maksimum tertinggi didapatkan pada konsentrasi pupuk ZA 40 $\mathrm{ml} / \mathrm{L}$ dengan nilai sebesar $18.910 \times 10^{3}$ sel/ml yang didapatkan pada jam ke-120 setelah penebaran. Fase pertumbuhan eksponensial populasi sel terjadi dalam selang waktu 24 jam setelah penebaran dengan laju pertumbuhan relatif tertinggi pada konsentrasi $40 \mathrm{ml} / \mathrm{L}$ pupuk ZA dengan nilai sebesar $292,71 \%$ dan menghasilkan waktu penggandaan diri paling singkat yaitu 12,04 jam dengan laju pertumbuhan spesifik sebesar $5,92 \%$ per jam.

\section{Saran}

Pada pengkulturan N. oculata sebaiknya dilakukan dengan kombinasi kultur yang terbaik yaitu pada konsentrasi $40 \mathrm{ml} / \mathrm{L}$ agar hasil kultur lebih optimal. Pada penelitian selanjutnya diharapkan dapat menganalisis terhadap faktor-faktor lain seperti padat penebaran, intensitas cahaya, pupuk dan kualitas air yang dapat mempengaruhi pertumbuhan populasi sel tersebut.

\section{DAFTAR PUSTAKA}

1. Afriza, Z., G. Diansyah, dan AI. Sunaryo. (2015). Pengaruh Pemberian Pupuk Urea $\left(\mathrm{CH}_{4} \mathrm{~N}_{2} \mathrm{O}\right)$ dengan Dosis Berbeda Terhadap Kepadatan Sel dan Laju Pertumbuhan Porphyridium sp. pada Kultur Fitoplankton Skala Laboratorium. Maspari Journal, volume 7(2), pages 33-40.

2. Andersen, AR. (2005). Alga Culturing Tehniques. Elsevier Academic Press. USA.

3. Anon, SMAT., MT. Kocer, and H. Erbas. (2009). Studies on Growth Marine Microalgae In Batch Cultures: III. Nannochloropsis oculata (eustigmatophyta). Departement of Basic Aquatic Sciences, Faculty of Aquaculture, Firat University, Elazig, Turkey. Asian Journal of Plant Sciences volume 4(6), pages 642-644.

4. Campaña-Torres, A., LR. Martínez-Córdova, M. Martínez-Porchas, JA López-Elías dan MA. Porchas-Cornejo.(2012). Productive response of Nannochloropsis oculata, cultured in different media andtheir efficiency as food for the rotifer Brachionus rotundiformis. $\Phi Y T O N$. volume 8 , pages $44-50$

5. Daefi, T. (2016). Pertumbuhan dan Kandungan Gizi Nannochloropsis sp. Yang diisolasi dari Lampung Mangrove Center dengan Pemberian Dosis Urea Berbeda pada Kultur Skala Laboratorium. Skripsi. Fakultas Matematika dan Ilmu Pengetahuan Alam Universitas Lampung. Lampung

6. Dominic, V., JS. Murali, and MC. Nisha. (2009). Phycoremediation Efficiency of Mikro Algae Chlorella vulgaris, Synechocystis salina, and Gloeocapsa gelatinosa. Department of Botany, Center for PG studies and Research, Sacred Heart College, Thevara, Ernakulam (Dt.). Kerala.

7. Hu, H. dan K. Gao. (2006). Response of Growth and Fatty Acid Compositions of Nannochloropsis sp. to Environmental Factors under Elevated $\mathrm{CO}_{2}$ Consentration. Biotechnol Lett. Volume 28, pages 987 - 992. 
8. Hu, Q. (2004). Environmental Effects on cell Composition. in : Handbook of Microalgal Culture: Biotechnology and applied phycology (Richmond, A., editor). Blackwell Publishing Ltd. : 83-93.

9. Ceballos, J., AH Llamas., TG. Galano dan H. Villarreal. (2006). Substitution of Chaetoceros muelleri by Spirulina platensis Meal in Diets for Litopenaeus schmitti larvae. Aquaculture, volume 260, pages 215 -220.

10. Kartikasari, D. (2010). Pengaruh Penggunaan Media yang Berbeda terhadap Kemampuan Penyerapan Logam Berat Pb Pada Nannochloropsis sp. Skripsi. Fakultas Pertanian Universitas Lampung. Lampung.

11. Mukhlis, A., Z. Abidin., dan I. Rahman. (2017). Pengaruh Konsentrasi Pupuk Ammonium Sulfat Terhadap Pertumbuhan Populasi Sel Nannochloropsis sp. BioWallacea Jurnal Ilmiah Ilmu Biologi, volume 3(3), pages 149 - 155.

12. Ogbonna, JC. and H. Tanaka. (2000). Light Requirement and Photosynthetic Cell Cultivation-Development of Process for Efficient Light Utilization in Photobioreactors. Jurnal Appl Phycol, volume (12), pages 207-218.

13. Pottier, L., J. Pruvost, J. Deremetz, JF. Cornet, J. Legrand, and CG. Dussap. (2005). A Fully Predictive Model For One-Dimensional Light Attenuation By Chlamydomonas reinhardtii in a Torus Photobioreactor. Biotechnol Bioeng. volume (91), pages 569-582.

14. Riduan., S. Hasibuan, dan NA. Pamukas. (2015). The effect of Urea Manuring Addition with Different Doses on the Abundance of Density Nannochloropsis sp. Jurnal Online Mahasiswa, volume 2(2).

15. Riesya, DA. dan T. Nurhidayati. (2013). Pengaruh Kombinasi Konsentrasi Media Ekstrak Tauge (MET) dengan Pupuk Urea Terhadap Kadar Protein Spirulina sp. Jurnal Sains dan Seni Pomits, volume 2(2), pages 2337 - 3520.

16. Rostini, I. (2007). Kultur Fitoplankton (Chlorella sp. dan Tetraselmis chuii) pada Skala Laboratorium. Skripsi. Jatinagor: Universitas Padjajaran. 